\title{
Effect of COVID-19 lockdown on metal concentration in the water column of Asia's largest coastal lagoon
}

\author{
${ }^{1}$ Syed Hillal Farooq, ${ }^{1}$ Amrit Kumar Mishra, ${ }^{1}$ Sandip Kumar Mohakud, ${ }^{2}$ Prasannjit \\ Acharya ${ }^{2}$ Pradipta Ranjan Muduli, ${ }^{1}$ Debadutta Swain
}

${ }^{1}$ School of Earth Ocean and Climate Sciences, Indian Institute of Technology, Bhubaneswar, Jatni, Khorda, Odisha, India

${ }^{2}$ Wetland Research and Training Center, Chilika Development Authority, Barkul, Balugaon, 752030, Odisha, India

Corresponding author: hilalfarooq@,iitbbs.ac.in

\begin{abstract}
:
A complete halt on all anthropogenic activities and human movement due to COVID-19 lockdown has provided a great opportunity to assess the impact of human activities on coastal marine ecosystems. The current study assessed the concentration of the metals in water samples of the largest brackish water lagoon of Asia; the Chilika lagoon in the state of Odisha, India between pre-COVID-19 and post-COVID-19 lockdown scenarios. Monthly water samples $(\mathrm{n}=30$ stations) from $0.3 \mathrm{~m}$ depth were collected from three sectors of the lagoon seasonally; pre-monsoon, monsoon, and post-monsoon. In addition to various physical parameters $[\mathrm{pH}$, salinity, alkalinity, (DO) dissolved oxygen, (TDS) total dissolved solids, and (EC) electrical conductivity] the collected water samples were analysed for 18 trace metals (Al, As, Ba, Be, $\mathrm{Cd}, \mathrm{Co}, \mathrm{Cr}, \mathrm{Cu}, \mathrm{Fe}, \mathrm{Mn}, \mathrm{Mo}, \mathrm{Ni}, \mathrm{Pb}, \mathrm{Sr}, \mathrm{Th}, \mathrm{Tl}, \mathrm{U}, \mathrm{V})$. Most of the physical parameters showed a significant variation between pre-and post-COVID-19 scenarios, except for $\mathrm{pH}$ and DO. The concentration of five metals $(\mathrm{Be}, \mathrm{Cd}, \mathrm{Co}, \mathrm{Ni}$, and $\mathrm{Pb})$ remained below detection limits in all water samples. The impact of COVID-19 lockdown on the concentration of the metal in the water samples was noticed along with the three sectors of the lagoon. However, eight metals (Al, As, Cr, Fe, Mn, Th, U, and V) were significantly different between the COVID-19 scenarios and the remaining five metals were not statistically significant. The mean concentration of $\mathrm{Al}$, As, Fe, Th, and V were higher in the pre-COVID-19 scenarios, whereas only $\mathrm{Cr}$ and $\mathrm{Mn}$ were higher in the post-COVID-19 scenarios. The mean concentration of $\mathrm{U}$ was similar among both COVID-19 scenarios, even though there were seasonal and sectoral differences. The seasonal influence of riverine influx was more evident on metal concentration during the monsoon season, whereas the difference between sectors was more prominent during the post-monsoon season. An increased number of correlations between physical parameters and metal concentration were observed in the post-monsoon season and postCOVID-19 scenario. This study provides evidence that the imposition of COVID-19 lockdown reduced metal influx in the water column and improved the water quality of the Chilika lagoon. Our results can be used as baseline for metal concentration in surface waters of the lagoon.
\end{abstract}

Keywords: Trace metals, COVID-19, Lagoon ecosystem, Anthropogenic pollution, Water quality, India 


\section{INTRODUCTION}

The spread of severe acute respiratory syndrome coronavirus-2 (SARS-CoV-2; hereafter called COVID-19) had an impact on the entire world human activities, as it spread across the globe (Cascella et al., 2020; WHO, 2021). Consequently, based on the repeated emergence, rapid transmission, and higher causality rate the WHO declared COVID-19 as a pandemic in March 2020. Following the declaration, in India, the COVID-19 led to a nationwide lockdown and shut down in mid-March 2020. This lockdown (March-October 2020) led to the suspension of almost all industrial and agricultural activities across the country, other than the essential services industry which was not closed. Under this lockdown period, industrial and human activities were significantly reduced. This period provided a window of opportunity to study the natural ecosystems under the lack of human-induced disturbances, which would otherwise not be possible. Various researchers in India used this opportunity to assess the air and water pollution status under the influence of the imposed lockdown and observed a reduction in various pollutants in the natural ecosystems (Garg et al., 2020; Lokhandwala and Gautam, 2020; Mishra et al., 2020; Patel et al., 2020). As major river systems discharge various anthropogenic derived pollutants to the coastal ecosystems of India, the lockdown also led to a reduction in coastal pollution (Mishra et al., 2020; Lotliker et al., 2021; Vijay Prakash et al., 2021). However, this lockdown resulted in a decline of phytoplankton biomass in the Bay of Bengal due to reduced input of nutrients (Mishra et al., 2020), whereas reduction in pollutants improved the surface water quality along both the east and the west coast of India (Vijay Prakash et al., 2021; Lotliker et al., 2021). However, these studies did not quantify the concentration of various metals in the coastal water column, which also plays an important role in maintaining water quality (Richir and Gobert, 2014). Consequently, the concentration of various trace metals was quantified in the river Ganga in India during this COVID-19 lockdown period and it was observed that due to lack of anthropogenic input there was a reduction in the input of around $50 \%$ of the metals in the water column (Shukla et al., 2021).

The coastal areas of India are dynamic ecosystems where there is a confluence of fresh and marine water. Being at the interface of land and marine systems these ecosystems receive river discharges, dredging, waste dumping, industrial effluents, domestic sewage disposal, and various other pollutants (Gopal et al., 2018; Vijay Prakash et al., 2021). This continuous input of anthropogenic pollutants exerts a significant impact on the coastal environments (Häder et al., 2020). As a result, coastal ecosystems act as a sink of contaminants including metals (Lewis and Richard, 2009). These metals play a critical role in marine ecosystem functioning (Avelar et al., 2013; Mishra et al., 2019; Morsy et al., 2020). Among these metals, some are essential micronutrients $(\mathrm{Cu}, \mathrm{Mn}, \mathrm{Zn}$, etc.) for the primary producers, whereas others act as non-essential and toxic to organisms ( $\mathrm{As}, \mathrm{Cd}, \mathrm{Cr}, \mathrm{Hg}$, and $\mathrm{Pb}$ ) when the concentration of these metals exceed threshold levels (Millero et al., 2009; Stockdale et al., 2016). In recent years, the coastal waters of India are experiencing water quality deterioration as a result of increasing anthropogenic activities and influx of these materials into the coastal waters (Tripathy et al., 2014; Mishra et al., 2015). Therefore, making it essential to monitor trace metals concentrations in the coastal waters.

Chilika lagoon in the state of Odisha, India is one such important coastal ecosystem that harbours a rich diversity of plants and animals and sustains considerable anthropogenic pressure from various fishing and tourism activities (Madhusmita, 2012; Mohanty et al., 2016). Considering its ecological significance, the nodal agency for monitoring of this lagoon, i.e., Chilika Development Authority (CDA) and various other researchers have monitored the water quality of this lagoon (Panda et al., 2010; Ganguly et al., 2015; Barik et al., 2019; Nazneen et 
al., 2019; and references therein). Consequently, various other studies have also monitored the metal concentration in the sediment of this lagoon (Banerjee et al., 2017; Barik et al., 2018; Nayak et al., 2004; Nazneen et al., 2019 and references therein) and fishes and crab tissues (Nayak et al., 2015; Parida et al., 2017; Panda et al., 2019). However, there is a significant lack of information on the metal concentrations in the water column of this lagoon, considering the positive impact of both riverine freshwater influx and saline water from the Bay of Bengal (Panda et al., 2015; Sahu et al., 2014).

However, there are few studies on the coastal waters of the Bay of Bengal on water quality and particulate matter (Mishra et al., 2020; Lotliker et al., 2021) which have been conducted during the lockdown period, but there are no such attempted studies to provide an overview of trace metals contamination or reduction during the COVID-19 lockdown. Secondly, the lockdown period due to COVID-19 provided an opportunity to assess this metals influx from riverine input as most of the human activities were suspended during this period. Therefore, the proposed study looks into the concentration of metals in the water samples of the Chilika lagoon, where there is an input of anthropogenic contaminants from various rivulets and agricultural activities.

The proposed study also quantifies the concentration of various metals in the surface water of the Chilika lagoon in three sectors; northern, central, southern, and three seasons; premonsoon, monsoon, and post-monsoon and compare the concentration of the metals between pre-COVID-19 (the year 2019-20) and post-COVID-19 (the year 2020-21) conditions. It is hypothesized that due to the implementation of lockdown and shutdown of industrial and human activities there should be a low concentration of metals in the post-COVID-19 scenarios. The study also measures the physical parameters of the lagoon and assesses the correlation between seasons, sectors, and metals concentration.

\section{METHODS}

Study site:

Chilika lagoon is Asia's largest freshwater lagoon spread across $1165 \mathrm{~km}^{2}$ (CDA, 2021). This lagoon is situated on the east coast of India in the state of Odisha of India (Fig.1). The lagoon consists of various habitats such as seagrasses, salt marshes, mudflats, and island ecosystems that make it one of the biodiverse ecosystems. It supports the livelihood of millions of coastal fishermen population and acts as a feeding and breeding ground for millions of migratory birds that come through the Central Asian Flyway (CDA, 2021). The cris-cross width of the lagoon is around $32 \mathrm{~km}$ long and the lagoon is connected with the Bay of Bengal through an artificially opened mouth (Sahu et al., 2014; Mohanty et al., 2016; Sahoo et al., 2018). Through this mouth, there is an input of saline water which influences the water characteristics of the lagoon (Barik et al., 2020). Other than this sea mouth, a few canals such as the Palur canal bring seawater into the southern part of the lagoon (Fig.1). Other than these inputs there are silt-borne freshwater discharges from the rivulets of the Mahanadi river, which drains into the lagoon in the northern part of the lagoon. Similarly, there is drainage from degraded catchment basins from the western and southern boundaries (Nazneen et al., 2019). For the current study the lagoon is divided into three sectors; northern sector ( $\mathrm{n}=8$ stations), central sector ( $\mathrm{n}=15$ stations), and southern sector ( $\mathrm{n}=7$ stations). 


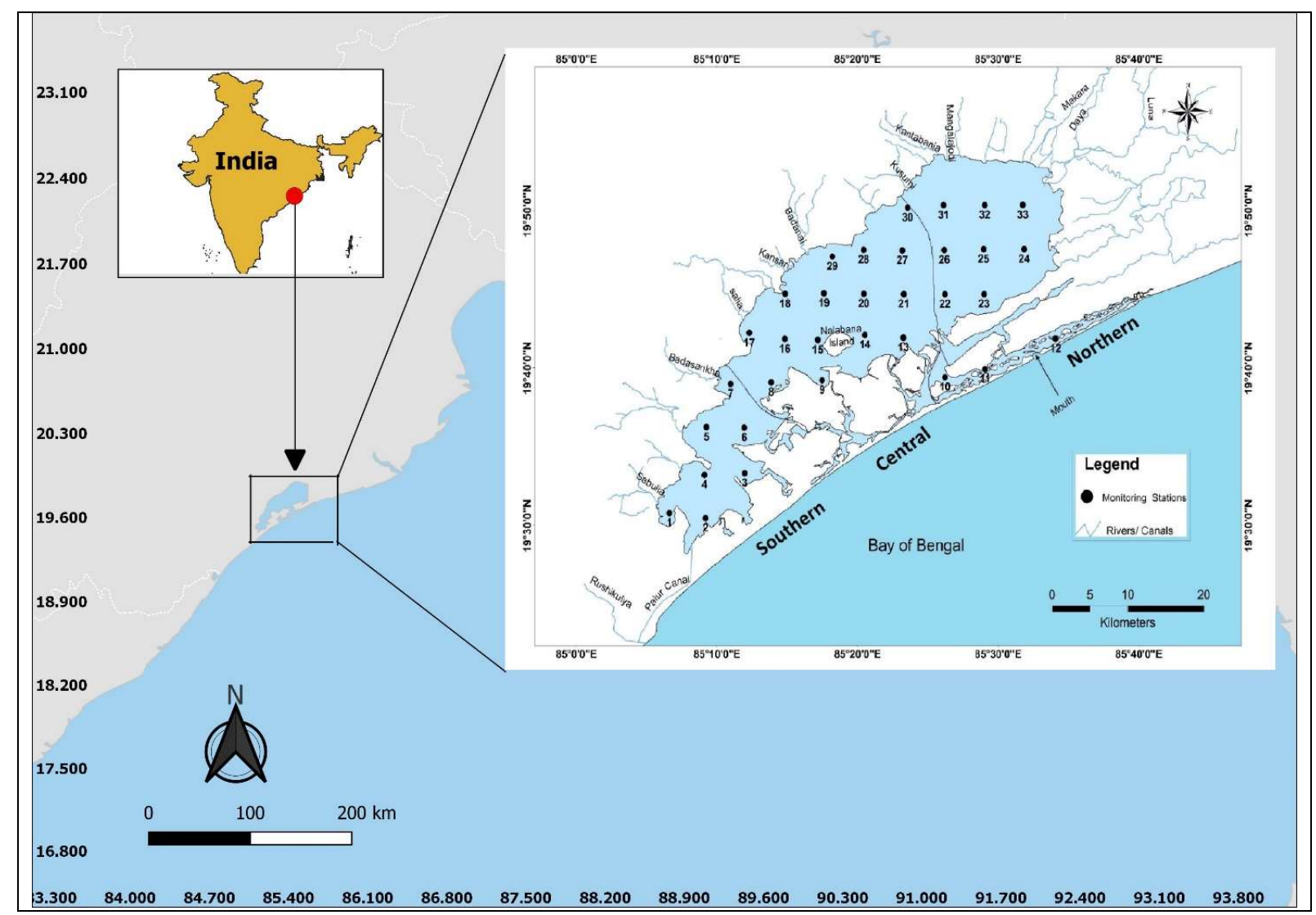

Fig. 1. Map showing the sampling locations and three sectors of the Chilika lagoon, Odisha, India.

\section{Sample collection and analysis}

Sampling was carried out from 30 prefixed locations by Wetland Research and Training Center (WRTC) of CDA, Odisha, which is the nodal agency for monitoring the water quality of the lagoon. Water samples were collected in May, July, September, November, and January of 2019, 2020, and 2021 and divided into pre-monsoon (May), Monsoon (July +September), and post-monsoon (November +January). Niskin sampler of $5 \mathrm{~L}$ was used to collect the subsurface $(0.3 \mathrm{~m})$ water samples from all the 30 stations in the three seasons for the year 201920 and 2020-21. Physical parameters of the water samples such as $\mathrm{pH}$, salinity, and electrical conductivity (EC) were measured using a water quality probe (SONDE, YSI, Model no. 6600, V2). Dissolved oxygen (DO) was quantified following the modified Winkler's method (Carpenter, 1996). Total alkalinity $\left(\mathrm{A}_{\mathrm{T}}\right)$ was measured following the acid titration method (APHA, 2005). All of these physical parameters were analyzed for respective parameters within 12 hours of sampling in the laboratory of WRTC, CDA, Odisha.

Nitric acid-washed $100 \mathrm{~mL}$ polyethylene bottles were used for the collection of water samples from the 30 stations. From each station $n=3$ replicates were collected, acidified with nitric acid $\left(0.5 \mathrm{~mL}\right.$ of $\mathrm{HNO}_{3}, 14 \mathrm{M}$ Ultrapure) transported to the laboratory in dark boxes, and were stored at $4^{\circ} \mathrm{C}$ till further analysis. 18 trace metals (Al, As, Cd, Co, Cr, Cu, Fe, Mn, Mo, $\mathrm{Ni}, \mathrm{Pb}, \mathrm{Sr}, \mathrm{Th}, \mathrm{Tl}, \mathrm{U}$, and V) were analyzed using ICP-OES (5110, Agilent, Dual view). Calibration curves were prepared by analyzing the standards (Mixed Certified Calibration Verification Standard, Agilent) of known concentrations. The concentration of metals in the 
water samples was determined by comparing the wavelength and intensities with reference to the calibration curve. The concentration of metals was expressed in $\mu \mathrm{g} / \mathrm{l}$ or $\mu \mathrm{g} / \mathrm{l}$ (parts per billion).

\section{Statistics}

Data are shown as mean \pm 1 standard deviation (SD) of the mean. A three-way ANOVA was used to test for significant differences in metals concentration and between physical parameters in the water samples among COVID-19 scenarios (fixed factor with 2 levels; preand post-COVID-19), seasons (fixed factor with 3 levels; pre-monsoon, monsoon, and postmonsoon) and sector (fixed factor with 3 levels; northern, central and southern) of the Chilika lagoon. All data were first checked for homogeneity of variances (Flinger test) and normality of distribution (Shapiro-Wilk's test). When ANOVA assumptions were not verified even after root-squared or $\log _{10}$ transformation, the Holm-Sidak test for multiple comparisons among factors and their interactions was used. Pearson correlation coefficient was used to test the correlation between physical parameters of the water samples and the concentration of the metals. All statistical tests were conducted with a significance level of $\alpha=0.05$. All statistical tests were conducted using SIGMAPLOT statistical software (ver.11.05).

\section{RESULTS}

\section{Physical parameters}

In general, the physical parameters of the Chilika lagoon varied significantly between the three sectors and seasons. The physical parameters were significant and different between the pre-and post-COVID-19 scenarios except for $\mathrm{pH}$ and DO (Table 1 and 2). Between the COVID-19 scenarios the average $\mathrm{pH}$, salinity, and DO were similar for the entire lagoon, whereas the TDS $(144.18 \pm 111 \mathrm{mg} / 1)$ and EC $(79.57 \pm 29 \mathrm{mS} / \mathrm{cm})$ were 11 -fold and 12-fold higher in the post-COVID than the pre-COVID-19 scenarios. In the pre-monsoon season, the TDS and EC of post-COVID scenarios were 3.2-fold and 2.8-fold higher than pre-COVID-19, whereas $\mathrm{pH}, \mathrm{A}_{\mathrm{T}}$, and salinity were 1-fold higher. In the monsoon season, the EC was 41-fold higher in the post-COVID than pre-COVID-19 scenario, whereas $\mathrm{pH}, \mathrm{A}_{\mathrm{T}}$, and salinity were 1fold lower in the post-COVID-19 scenarios. However, in the post-monsoon season, the EC was 16-fold higher in the post-COVID-19 scenario, whereas $\mathrm{pH}$, salinity, and DO were 1-fold lower than pre-COVID-19 scenario (Table 1). In the pre-COVID-19 scenario and seasons, the southern sector of the lagoon has the highest mean values for most parameters except DO, whereas in the post-COVID-19 scenario the southern sector has higher values for $\mathrm{pH}, \mathrm{A}_{\mathrm{T}}$ and salinity and the northern sector for DO, TDS, and EC (Table 1).

\section{Metals content in the water}

Out of the 18 trace metals analysed in the water samples, the concentration of five metals $(\mathrm{Be}$, $\mathrm{Cd}, \mathrm{Co}, \mathrm{Ni}$, and $\mathrm{Pb}$ ) were found to be below the detection limit at the majority of the stations. Out of the remaining 13 trace metals, the concentration was significant and different for 8 metals, except for $\mathrm{Ba}, \mathrm{Cu}, \mathrm{Mo}, \mathrm{Sr}$, and $\mathrm{Tl}$ (Fig.2 and 3 and Table 3).

\section{Pre-monsoon season}

In the pre-monsoon season, the concentration of metals such as $\mathrm{Al}, \mathrm{As}, \mathrm{Fe}$, and Th were higher in the pre-COVID-19 scenarios than post-COVID-19, whereas the concentration of Mn was higher in post-COVID-19, and metals like Cr, U, and V were similar between both COVID-19 scenarios (Fig.2 and 3). The mean concentration of $\mathrm{Al}(132.53 \pm 25.63 \mu \mathrm{g} / \mathrm{l})$, As $(9.72 \pm 1.24$ $\mu \mathrm{g} / \mathrm{l}), \mathrm{Fe}(40.67 \pm 2.20 \mu \mathrm{g} / \mathrm{l})$, and Th $(3.21 \pm 0.46 \mu \mathrm{g} / \mathrm{l})$ in the pre-COVID-19 were 2 -fold, 1.2 fold, 1-fold and 1-fold higher than the post-COVID-19 scenario respectively (Fig. 4a and b). 


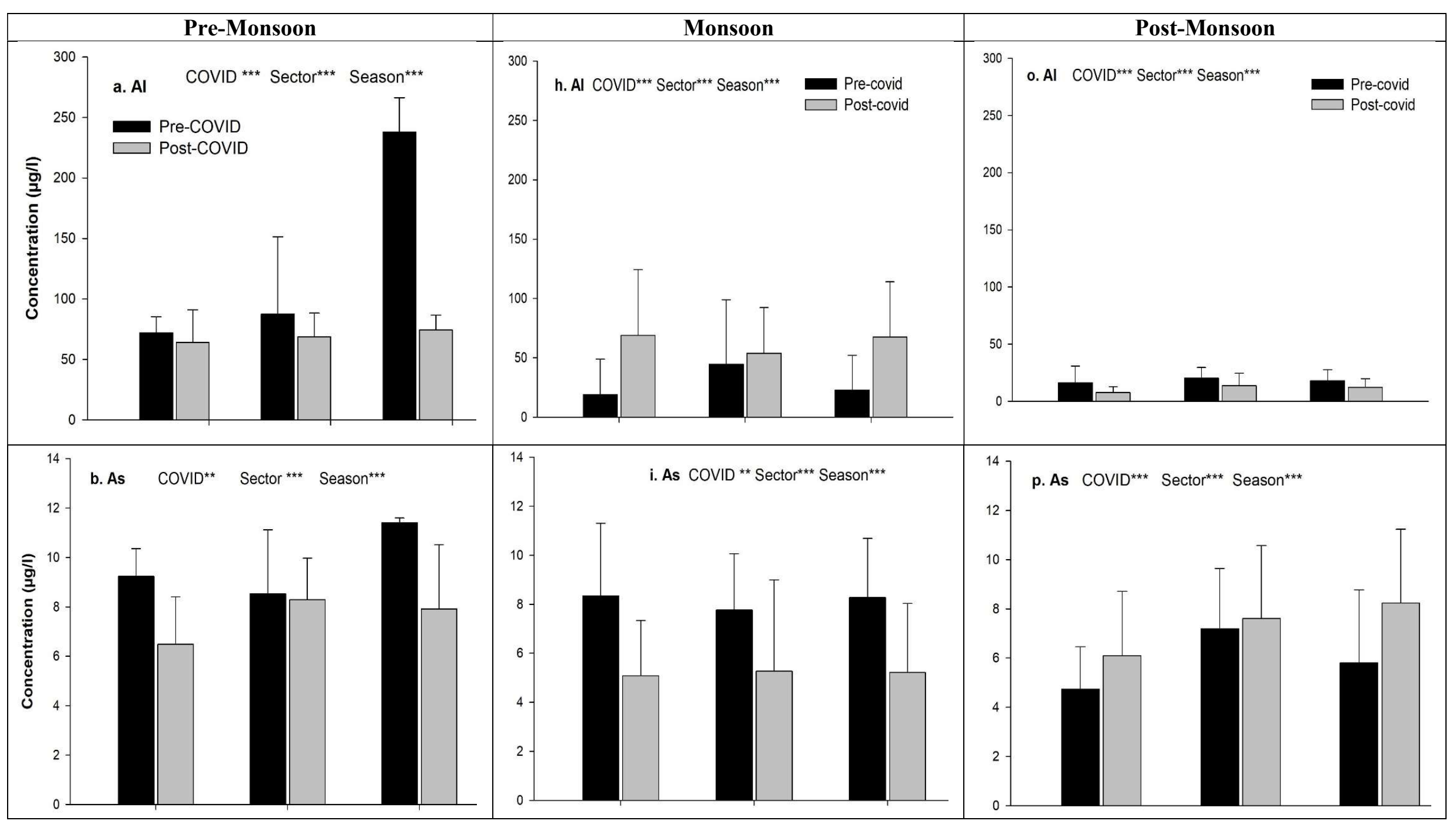




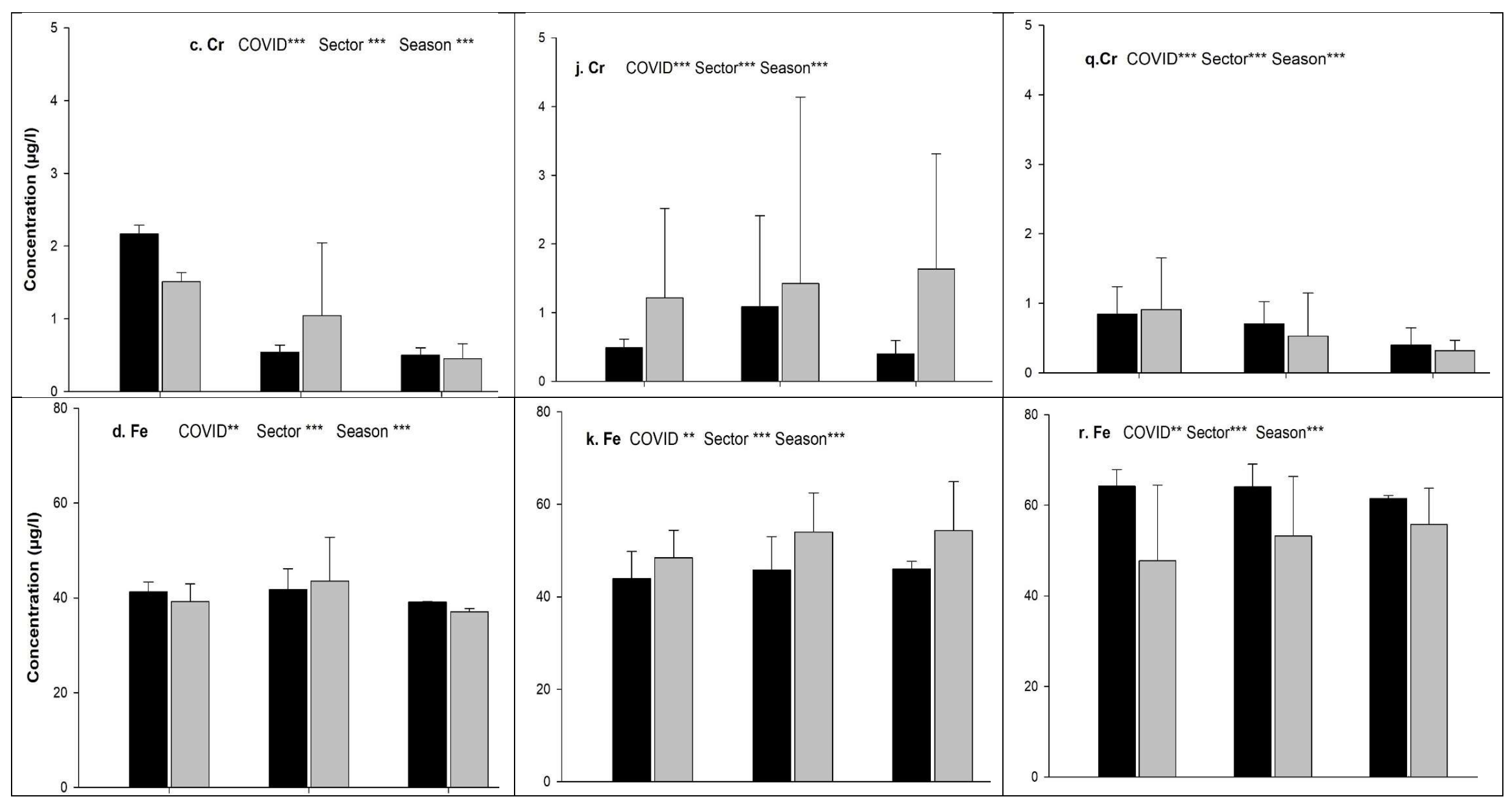




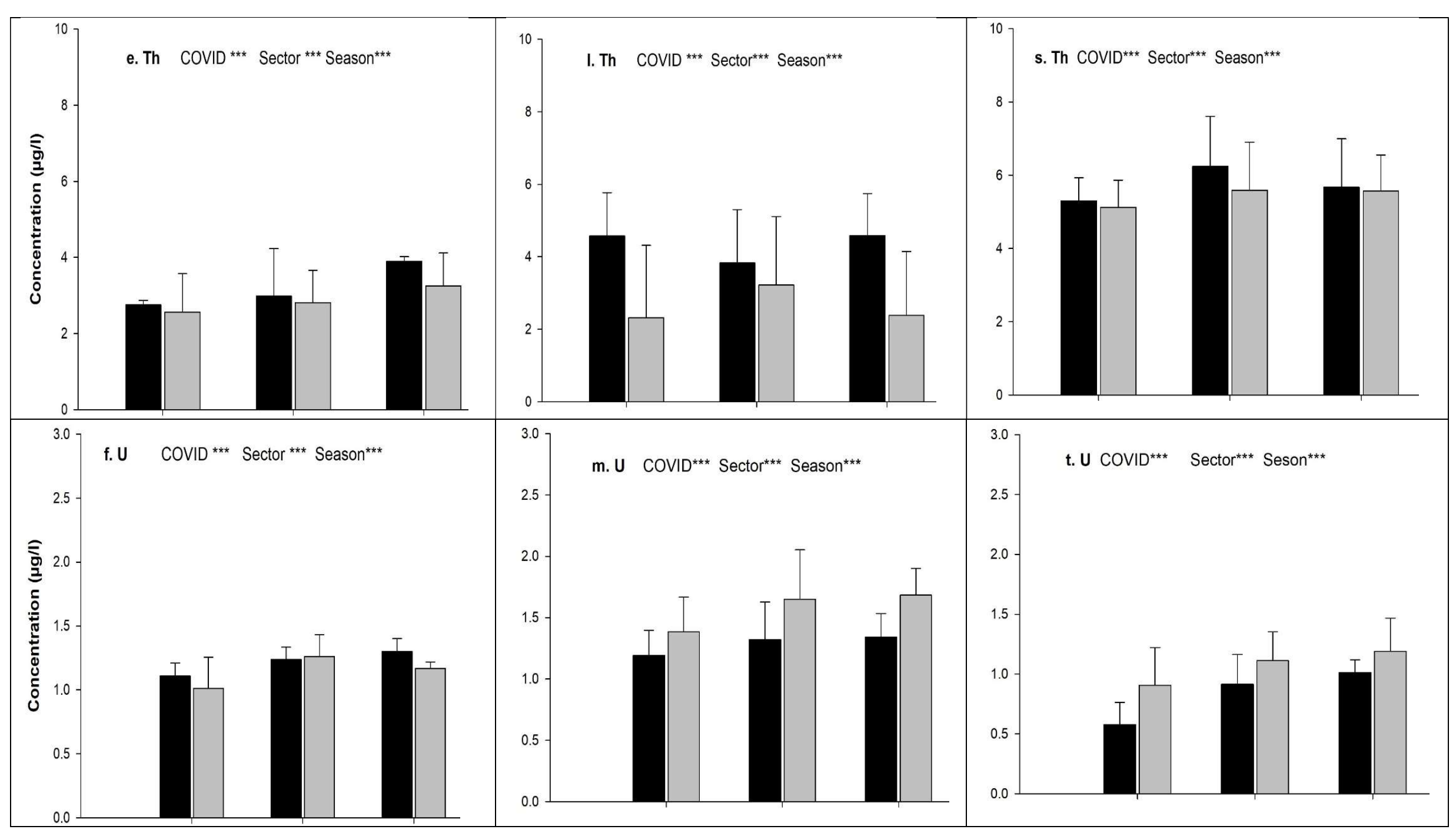




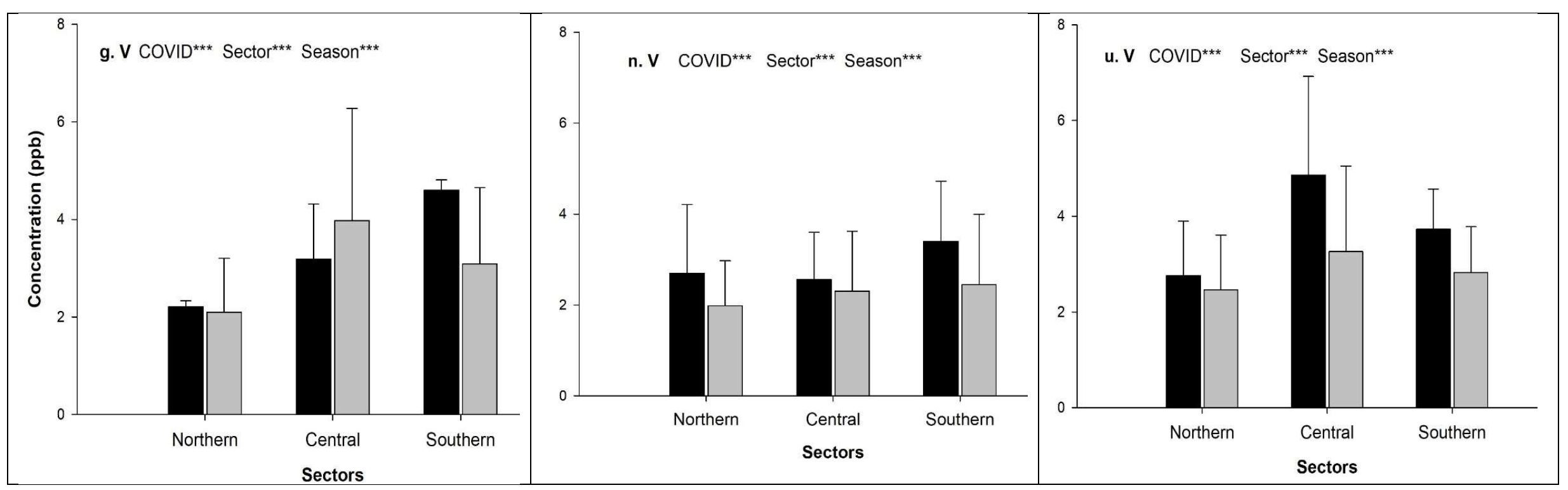

Fig.2. Metal concentration (mean $\pm \mathrm{SD}$ ) in the surface water of the Chilika lagoon within three sectors and seasons in pre- and post-COVID scenarios. Common elements with statistical significance between the three factors (COVID, sectors and seasons) derived from three-way ANOVA analysis are presented. Significance level $\left(\mathrm{p}<0.001^{* * *}, \mathrm{p}<0.01^{* *}, \mathrm{p}<0.05^{*}\right)$. 


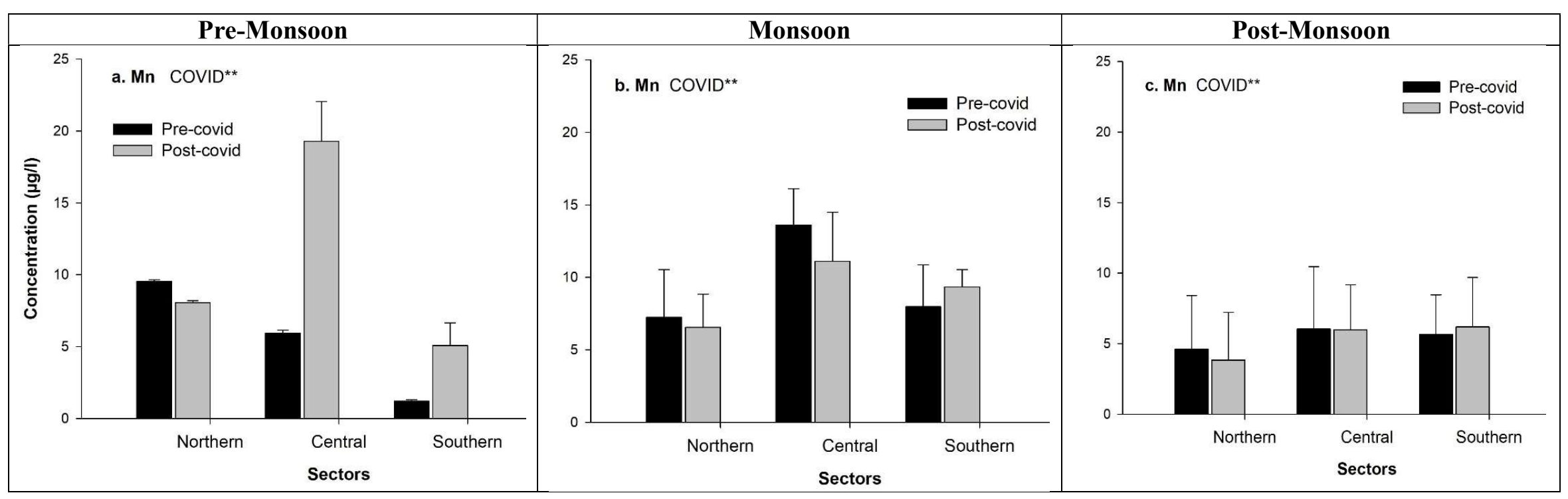

Fig.3. Metal concentration (mean $\pm \mathrm{SD}$ ) in the surface water of the Chilika lagoon within three sectors and seasons in pre- and post-COVID scenarios. Common elements with statistical significance between the COVID scenarios and not within seasons or sectors derived from three-way ANOVA analysis are presented. Significance level $\left(\mathrm{p}<0.001^{* * *}, \mathrm{p}<0.01^{* *}, \mathrm{p}<0.05^{*}\right)$. 


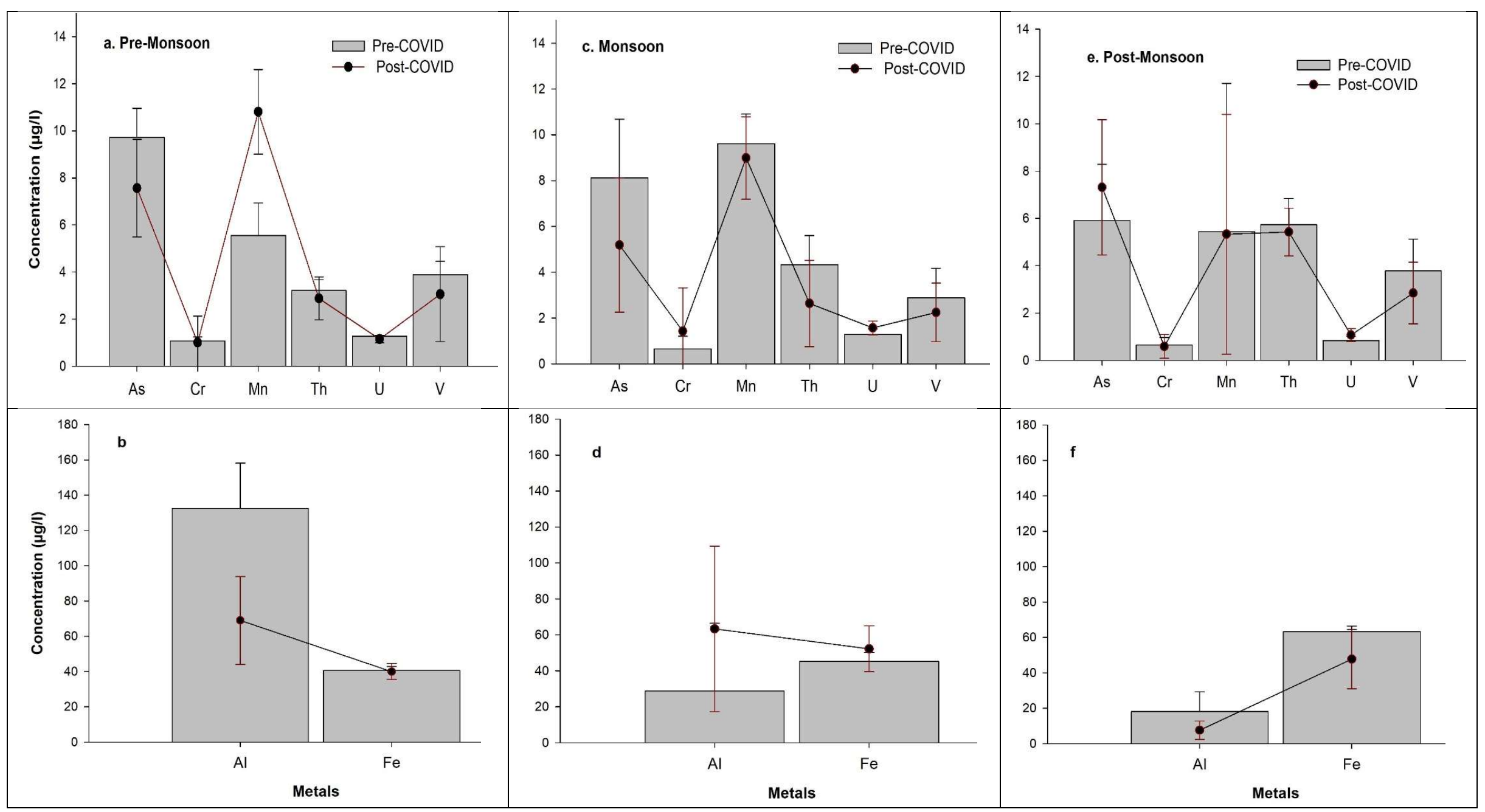

Fig.4 Mean metal concentration \pm standard deviation of statistically significant elements (Al, As, Cr, Fe, Mn, Th, U and V) in post-COVID scenarios between sectors and seasons are plotted against pre-COVID scenarios. Elements such as $\mathrm{Al}$ and Fe are separated due to their high concentration than other elements for better representation. Pre-monsoon (a and b), monsoon (c and d) and post-monsoon (e and f). 
Table 1. Physical parameters of the water samples of the Chilika lagoon. pH (Total Scale units, TS), alkalinity (A $\mathrm{A}_{\mathrm{T}}$, mg/l), Dissolved oxygen (DO, ppm), Total dissolved solids (TDS, mg/l), Electrical conductivity (EC, milli Siemens/cm).

\begin{tabular}{|c|c|c|c|c|c|c|c|}
\hline \multirow{2}{*}{ Seasons } & & \multicolumn{3}{|c|}{ Pre-COVID } & \multicolumn{3}{|c|}{ Post-COVID } \\
\hline & & \multicolumn{3}{|c|}{ Sectors } & \multicolumn{3}{|c|}{ Sectors } \\
\hline \multirow[t]{4}{*}{ Pre-Monsoon } & $\mathrm{pH}(\mathrm{TS})$ & $7.71 \pm 0.38$ & $8.11 \pm 0.27$ & $8.13 \pm 0.38$ & $8.47 \pm 0.57$ & $8.48 \pm 0.56$ & $8.78 \pm 0.24$ \\
\hline & Salinity & $4.76 \pm 4.14$ & $16.49 \pm 5.20$ & $11.85 \pm 0.51$ & $4.28 \pm 4.01$ & $11.07 \pm 9.54$ & $8.32 \pm 0.97$ \\
\hline & DO (ppm) & $7.56 \pm 1.22$ & $7.38 \pm 1.28$ & $6.38 \pm 1.67$ & $7.74 \pm 1.57$ & $6.64 \pm 1.93$ & $7.60 \pm 1.42$ \\
\hline & TDS (mg/l) & $6.55 \pm 5.58$ & $20.76 \pm 6.65$ & $15.78 \pm 0.54$ & $123.45 \pm 21.5$ & $10.95 \pm 6.88$ & $6.98 \pm 0.75$ \\
\hline \multirow{6}{*}{ Monsoon } & $\mathrm{pH}(\mathrm{TS})$ & $7.82 \pm 0.39$ & $8.10 \pm 0.17$ & $8.22 \pm 0.15$ & $7.81 \pm 0.31$ & $7.90 \pm 0.27$ & $8.03 \pm 0.45$ \\
\hline & $\mathrm{A}_{\mathrm{T}}(\mathrm{mg} / \mathrm{l})$ & $1.49 \pm 1.55$ & $6.89 \pm 2.71$ & $11.47 \pm 1.28$ & $0.66 \pm 0.78$ & $6.51 \pm 3.66$ & $9.37 \pm 0.34$ \\
\hline & Salinity & $123 \pm 14.68$ & $133 \pm 19.73$ & $156 \pm 13.24$ & $110 \pm 27.38$ & $130.3 \pm 19.5$ & $141.42 \pm .9 .3$ \\
\hline & $\mathrm{DO}(\mathrm{ppm})$ & $8.51 \pm 1.31$ & $7.81 \pm 1.40$ & $6.59 \pm 0.66$ & $8.11 \pm 1.09$ & $8.09 \pm 0.77$ & $7.94 \pm 1.15$ \\
\hline & TDS (mg/l) & $0.11 \pm 0.04$ & $1.86 \pm 2.08$ & $7.69 \pm 1.61$ & $137 \pm 125.8$ & $120.3 \pm 16.6$ & $7.81 \pm 0.26$ \\
\hline & $\mathrm{EC}(\mathrm{mS} / \mathrm{cm})$ & $0.24 \pm 0.10$ & $3.72 \pm 4.02$ & $15.67 \pm 3.36$ & $434 \pm 44.4$ & $361 \pm 52.1$ & $15.94 \pm 0.54$ \\
\hline \multirow{4}{*}{ Post-Monsoon } & Salinity & $0.41 \pm 0.18$ & $3.99 \pm 1.80$ & $6.73 \pm 0.46$ & $0.54 \pm 0.43$ & $3.80 \pm 1.44$ & $6.49 \pm 0.70$ \\
\hline & $\mathrm{DO}(\mathrm{ppm})$ & $9.70 \pm 0.95$ & $9.24 \pm 0.74$ & $8.52 \pm 0.48$ & $8.72 \pm 1.25$ & $7.82 \pm 0.93$ & $7.79 \pm 1.11$ \\
\hline & TDS (mg/l) & $0.35 \pm 0.16$ & $3.37 \pm 1.41$ & $5.75 \pm 0.36$ & $232 \pm 104$ & $70.48 \pm 138$ & $5.51 \pm 0.50$ \\
\hline & $\mathrm{EC}(\mathrm{mS} / \mathrm{cm})$ & $0.73 \pm 0.35$ & $6.41 \pm 3.13$ & $11.77 \pm 0.69$ & $162 \pm 53$ & $135 \pm 265$ & $11.25 \pm 1.02$ \\
\hline
\end{tabular}


Table 2. Significant difference of various physical parameters of the water samples between pre- and post-COVID scenarios, seasons and within the three sectors of the Chilika lagoon derived from three-way ANOVA analysis at significance level $(\mathrm{p}<0.05)$ are presented. Significant $p$ values are highlighted in bold. Pre-monsoon (Pre-M), Monsoon (M), Post-Monsoon (Post-M), Southern (S), Central (C), Northern (N).

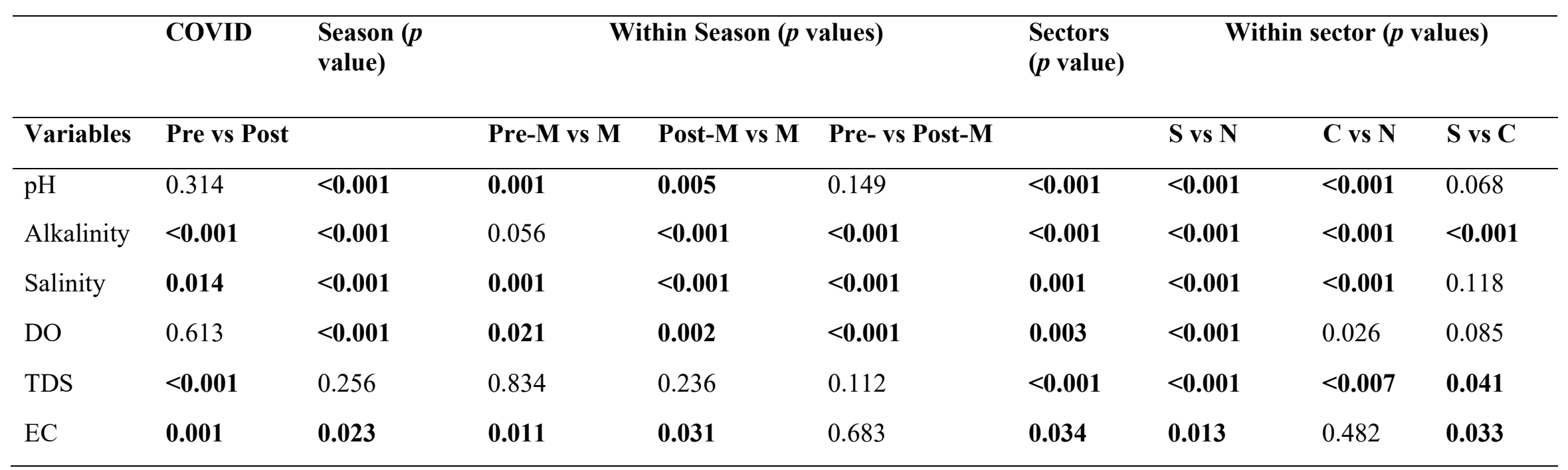


Table 3. Significant difference between element concentration in the water samples between pre- and post-COVID scenarios, seasons and within the three sectors of the Chilika lagoon derived from three-way ANOVA analysis at significance level $(\mathrm{p}<0.05)$ are presented. Significant $p$ values are highlighted in bold. Pre-monsoon (Pre-M), Monsoon (M), Post-Monsoon (Post-M), Southern (S), Central (C), Northern (N).

\begin{tabular}{|c|c|c|c|c|c|c|c|c|c|}
\hline \multirow[b]{2}{*}{ Element } & \multirow{2}{*}{$\begin{array}{l}\text { COVID } \\
\text { Pre vs Post }\end{array}$} & \multirow{2}{*}{$\begin{array}{l}\text { Season ( } p \\
\text { value) }\end{array}$} & \multicolumn{3}{|c|}{ Within Season ( $p$ values) } & \multirow{2}{*}{$\begin{array}{l}\text { Sectors } \\
(p \text { value })\end{array}$} & \multicolumn{3}{|c|}{ Within sector ( $p$ values) } \\
\hline & & & Pre-M vs M & Post-M vs M & Pre- vs Post-M & & S vs N & C vs N & S vs $\mathbf{C}$ \\
\hline $\mathrm{Al}$ & 0.002 & $<0.001$ & $<0.001$ & $<0.001$ & $<0.001$ & $<0.001$ & $<0.001$ & $<0.001$ & $<0.001$ \\
\hline As & 0.023 & 0.003 & $<0.001$ & 0.023 & 0.265 & $<0.001$ & $<0.001$ & $<0.001$ & 0.319 \\
\hline $\mathrm{Ba}$ & 0.324 & $<0.001$ & 0.394 & $<0.001$ & $<0.001$ & $<0.001$ & $<0.001$ & $<0.001$ & 0.079 \\
\hline $\mathrm{Cr}$ & $<0.001$ & $<0.001$ & 0.438 & $<0.001$ & $<0.001$ & $<0.001$ & $<0.001$ & $<0.001$ & 0.485 \\
\hline $\mathrm{Cu}$ & 0.094 & $<0.001$ & $<0.001$ & 0.179 & 0.019 & 0.424 & 0.250 & 0.265 & 0.984 \\
\hline $\mathrm{Fe}$ & 0.038 & $<0.001$ & $<0.001$ & $<0.001$ & $<0.001$ & $<0.001$ & $<0.001$ & $<0.001$ & 0.022 \\
\hline $\mathrm{Mn}$ & 0.015 & 0.488 & 0.249 & 0.393 & 0.760 & 0.176 & 0.065 & 0.260 & 0.463 \\
\hline Mo & 0.155 & $<0.001$ & $<0.001$ & $<0.001$ & 0.747 & $<0.001$ & $<0.001$ & $<0.001$ & 0.864 \\
\hline $\mathrm{Sr}$ & 0.508 & $<0.001$ & $<0.001$ & $<0.001$ & $<0.001$ & $<0.001$ & $<0.001$ & $<0.001$ & 0.973 \\
\hline Th & $<0.001$ & $<0.001$ & 0.832 & $<0.001$ & $<0.001$ & $<0.001$ & $<0.001$ & $<0.001$ & 0.979 \\
\hline $\mathrm{Tl}$ & 0.372 & $<0.001$ & 0.002 & $<0.001$ & $<0.001$ & $<0.001$ & $<0.001$ & 0.018 & 0.060 \\
\hline $\mathrm{U}$ & $<0.001$ & $<0.001$ & 0.002 & $<0.001$ & $<0.001$ & $<0.001$ & $<0.001$ & $<0.001$ & 0.326 \\
\hline V & $<0.001$ & $<0.001$ & 0.003 & $<0.001$ & $<0.001$ & $<0.001$ & $<0.001$ & $<0.001$ & 0.843 \\
\hline
\end{tabular}


The mean concentration of $\mathrm{Mn}(10.81 \pm 1.8 \mu \mathrm{g} / \mathrm{l})$ in the post-COVID-19 scenario was 2-fold higher than pre-COVID-19 (Fig.4). The concentration of Al and As in the pre-monsoon season of pre-COVID-19 was highest among seasons and sectors (Fig.4a and b). In the pre-monsoon season, between sectors and COVID-19 scenarios, the concentration of various metals did not follow a similar pattern of increase or decrease (Table 4). The concentration of Al and Th between sectors followed a similar pattern of increase in both COVID-19 scenarios. Whereas metals like As, $\mathrm{U}$, and $\mathrm{V}$ followed a similar pattern in the pre-COVID-19 and a different pattern in the post-COVID-19 scenarios (Table 4).

Table 4. Mean concentration \pm standard deviation of statistically significant elements in preand post-COVID scenarios between sectors and seasons. The pattern of increase or decrease of element concentration is presented. Bold letters indicate the pattern is same in pre-and post-COVID scenarios. Southern (S) Central (C) and Northern (N)

\begin{tabular}{|c|c|c|c|}
\hline Season & Elements & Pre-COVID & Post-COVID \\
\hline \multirow[t]{8}{*}{ Pre-Monsoon } & $\mathrm{Al}$ & $\mathbf{S}>\mathbf{C}>\mathbf{N}$ & $\mathbf{S}>\mathbf{C}>\mathbf{N}$ \\
\hline & As & $S>C>N^{*}$ & $C>S>N^{*}$ \\
\hline & $\mathrm{Cr}$ & $\mathrm{N}>\mathrm{S}=\mathrm{C}$ & $\mathrm{N}>\mathrm{C}>\mathrm{S} \#$ \\
\hline & $\mathrm{Fe}$ & $\mathrm{C}=\mathrm{N}>\mathrm{S} \#$ & $\mathrm{C}>\mathrm{N}>\mathrm{S} \#$ \\
\hline & Mn & $\mathrm{N}>\mathrm{C}>\mathrm{S}$ & $\mathrm{C}>\mathrm{N}>\mathrm{S} \#$ \\
\hline & Th & $\mathbf{S}>\mathbf{C}>\mathbf{N}$ & $\mathbf{S}>\mathbf{C}>\mathbf{N}$ \\
\hline & $\mathrm{U}$ & $\mathrm{S}>\mathrm{C}>\mathrm{N}$ & $\mathrm{C}<\mathrm{S}>\mathrm{N}^{*}$ \\
\hline & V & $\mathrm{S}>\mathrm{C}>\mathrm{N}$ & $\mathrm{C}<\mathrm{S}>\mathrm{N}^{*}$ \\
\hline \multirow[t]{8}{*}{ Monsoon } & $\mathrm{Al}$ & $\mathrm{C}>\mathrm{S}>\mathrm{N}$ & $\mathrm{N}>\mathrm{S}>\mathrm{C}$ \\
\hline & As & $\mathrm{S}=\mathrm{N}>\mathrm{C} \#$ & $\mathrm{C}=\mathrm{S}>\mathrm{N}$ \\
\hline & $\mathrm{Cr}$ & $\mathrm{C}>\mathrm{N}>\mathrm{S}$ & $\mathrm{S}>\mathrm{C}>\mathrm{N} \#$ \\
\hline & $\mathrm{Fe}$ & $\mathbf{C}=\mathbf{S}>\mathbf{N}$ & $\mathbf{C}=\mathbf{S}>\mathbf{N}$ \\
\hline & $\mathrm{Mn}$ & $\mathbf{C}>\mathbf{S}>\mathbf{N}$ & $\mathbf{C}>\mathbf{S}>\mathbf{N}$ \\
\hline & Th & $\mathrm{S}=\mathrm{N}>\mathrm{C} \#$ & $\mathrm{C}>\mathrm{S}=\mathrm{N}$ \\
\hline & $\mathrm{U}$ & $\mathbf{C}=\mathbf{S}>\mathbf{N}$ & $\mathbf{C}=\mathbf{S}>\mathbf{N}$ \\
\hline & V & $\mathrm{S}>\mathrm{N}>\mathrm{C}$ & $\mathrm{C}=\mathrm{S}>\mathrm{N} \#$ \\
\hline \multirow[t]{8}{*}{ Post-Monsoon } & $\mathrm{Al}$ & $\mathbf{C}>\mathbf{S}>\mathbf{N}$ & $\mathbf{C}>\mathbf{S}>\mathbf{N}$ \\
\hline & As & $\mathrm{C}>\mathrm{S}>\mathrm{N}$ & $\mathrm{S}>\mathrm{C}>\mathrm{N} \#$ \\
\hline & $\mathrm{Cr}$ & $\mathbf{N}>\mathbf{C}>\mathbf{S}$ & $\mathbf{N}>\mathbf{C}>\mathbf{S} \#$ \\
\hline & $\mathrm{Fe}$ & $\mathrm{C}=\mathrm{N}>\mathrm{S} \#$ & $\mathrm{~S}>\mathrm{C}>\mathrm{N} \#$ \\
\hline & $\mathrm{Mn}$ & $\mathrm{C}>\mathrm{S}>\mathrm{N}$ & $\mathrm{S}>\mathrm{C}>\mathrm{N} \#$ \\
\hline & Th & $\mathbf{C}>\mathbf{S}>\mathbf{N}$ & $\mathbf{C}>\mathbf{S}>\mathbf{N}$ \\
\hline & $\mathrm{U}$ & $\mathbf{S}>\mathbf{C}>\mathbf{N}$ & $\mathbf{S}>\mathbf{C}>\mathbf{N}$ \\
\hline & $\mathrm{V}$ & $\mathbf{C}>\mathbf{S}>\mathbf{N}$ & $\mathbf{C}>\mathbf{S}>\mathbf{N}$ \\
\hline
\end{tabular}

$(*)$ indicate the patterns are different between pre-and post-COVID, but similar patterns are observed for different elements.

(\#) indicates similar pattern for an element between seasons or COVID scenarios. 


\section{Monsoon season}

The mean concentration of metals like Al $(63.31 \pm 46.84 \mu \mathrm{g} / 1), \mathrm{Cr}(1.42 \pm 1.89 \mu \mathrm{g} / \mathrm{l}), \mathrm{Fe}$ $(52.21 \pm 12.71)$, and $U(1.57 \pm 0.30 \mu \mathrm{g} / \mathrm{l})$ were 2-fold, 2.1 -fold and 1-fold and 1.2-fold higher in the monsoon season for post-COVID-19 than pre-COVID-19 scenarios respectively (Fig.2, 3 and $4 \mathrm{c}$ and $\mathrm{d})$. Whereas the concentration of metals like As $(8.13 \pm 2.56 \mu \mathrm{g} / \mathrm{l}), \mathrm{Mn}(9.61$ $\pm 1.3 \mu \mathrm{g} / \mathrm{l})$, Th $(4.33 \pm 1.28 \mu \mathrm{g} / \mathrm{l})$, and V $(2.89 \pm 1.29 \mu \mathrm{g} / \mathrm{l})$ was 1.5 -fold, 1 -fold, 1.6 -fold, and 1.2fold higher in pre-COVID-19 scenarios respectively (Fig.2, 3 and 4). For the monsoon season, the concentration of $\mathrm{Cr}$ and $\mathrm{U}$ in the post-COVID-19 scenarios were the highest among seasons and sectors (Fig.4c and d). The concentration of metals like Fe, Mn, and $\mathrm{U}$ in the monsoon season between COVID-19 scenarios followed a similar pattern of increase, whereas As and Th followed a similar pattern of increase in pre-COVID-19 scenarios, and $\mathrm{Cr}$ and $\mathrm{V}$ followed a similar pattern in post-COVID-19 scenarios (Table 4).

\section{Post-monsoon season}

In the post-monsoon season, the mean concentration of As $(7.31 \pm 2.60 \mu \mathrm{g} / \mathrm{l})$ and $\mathrm{U}(1.07 \pm$ $0.31 \mu \mathrm{g} / \mathrm{l}$ ) were 1.2-fold higher in post-COVID-19 than in the pre-COVID-19 scenarios (Fig.2 and 4). However, the concentration of $\mathrm{Al}(18.14 \pm 11.17 \mu \mathrm{g} / \mathrm{l}), \mathrm{Cr}(0.64 \pm 0.32 \mu \mathrm{g} / \mathrm{l}), \mathrm{Fe}(63.25$ $\pm 3.12 \mu \mathrm{g} / \mathrm{l}), \mathrm{Mn}(5.44 \pm 6.26 \mu \mathrm{g} / \mathrm{l})$, Th $(5.78 \pm 1.10 \mu \mathrm{g} / \mathrm{l})$, and $\mathrm{V}(3.78 \pm 1.34 \mu \mathrm{g} / \mathrm{l})$ were 1.6fold, 1.1-fold, 1.2-fold, 1-fold, 1-fold and 1.3-fold higher than post-COVID-19 scenario respectively (Fig.2 and 4e and f). Most of the metals (Al, Cr, Th, U, and V) followed the same pattern on increase between both COVID-19 scenarios, exception was As, Fe, and Mn (Table 4). The highest concentration of $\mathrm{As}, \mathrm{Fe}$, and $\mathrm{Mn}$ followed a similar pattern of distribution in post-COVID-19 than pre-COVID-19 scenarios (Table 4).

\section{Correlation}

The correlation between physical parameters and metals concentration in the water column was significant only for a few metals and parameters for the COVID-19 scenarios (Table 5). In the pre-monsoon season, a higher number of correlations between physical parameters and metals were observed in pre-COVID-19 than post-COVID-19 scenarios (Table 5). In the pre-COVID19 scenario $\mathrm{pH}$ was observed with a negative correlation with $\mathrm{Ba}, \mathrm{Mo}$, and $\mathrm{U}$, and in postCOVID-19 with Ba (Table 5). For $\mathrm{A}_{\mathrm{T}}$, there were positive correlations with $\mathrm{Th}$ and $\mathrm{V}$ in preCOVID-19 scenarios and no correlation in the post-COVID-19. Salinity was positively correlated with Mo and U in pre-COVID-19, Al, and Mn in the post-COVID-19. Though there were positive and negative correlations between TDS and EC with Mn and Mo in pre-COVID19, no such interactions were observed for the post-COVID-19 (Table 5).

For the monsoon season, only $\mathrm{U}$ and $\mathrm{V}$ were observed with a positive correlation with most physical parameters in pre-and post-COVID-19 scenarios (Table 5). There were no correlations in the pre-COVID-19 scenario with $\mathrm{pH}$, except for U, whereas in post-COVID-19 only Cr was positively correlated with $\mathrm{pH}$. The metals As and Mo were positively correlated with salinity only in the post-COVID-19 scenario, whereas $U$ is positively correlated with salinity in both COVID-19 scenarios. DO was only positively correlated with $\mathrm{Tl}$ in the pre-COVID-19, whereas there were no correlations with DO and EC in the post-COVID-19 scenario. AT was positively correlated with $T h$ and $U$ in pre-COVID-19 and with only $U$ in post-COVID-19. With TDS, U was positively correlated in pre-COVID-19 and negatively correlated in postCOVID-19 (Table 5). 
Table 5. Correlation between physical parameters and element concentration in the water samples among seasons and COVID scenarios of the Chilika lagoon. Pearson correlation co-efficient and $p$ values are presented (in bold) which showed a significant positive or negative correlation. Alkalinity (AT), Dissolved oxygen (DO), Total dissolved solids (TDS), Electrical conductivity (EC), Salinity (S)

\begin{tabular}{|c|c|c|c|c|c|c|c|c|c|c|c|c|}
\hline \multirow[t]{2}{*}{ Season } & \multicolumn{2}{|c|}{ Elements } & \multicolumn{5}{|c|}{ Pre-COVID } & \multicolumn{5}{|c|}{ Post-COVID } \\
\hline & & pH & $\mathbf{A}_{\mathbf{T}}$ & $\mathbf{S}$ & DO & TDS & EC & pH & $\mathbf{A}_{\mathbf{T}}$ & $\mathbf{S}$ & TDS & $\mathbf{E C}$ \\
\hline \multirow[t]{7}{*}{ Pre-Monsoon } & $\mathrm{Al}$ & - & - & - & - & - & - & - & - & $\begin{array}{l}0.469 \\
\mathbf{0 . 0 1}\end{array}$ & - & - \\
\hline & $\mathrm{Ba}$ & $\begin{array}{l}-0.622 \\
\mathbf{0 . 0 0 3}\end{array}$ & - & - & - & - & - & $\begin{array}{l}-0.534 \\
\mathbf{0 . 0 0 2}\end{array}$ & - & - & - & - \\
\hline & $\mathrm{Mn}$ & - & - & - & - & $\begin{array}{l}0.801 \\
\mathbf{0 . 0 0 3}\end{array}$ & - & - & - & $\begin{array}{l}0.451 \\
\mathbf{0 . 0 1}\end{array}$ & - & - \\
\hline & Mo & $\begin{array}{l}-0.414 \\
\mathbf{0 . 0 2}\end{array}$ & & $\begin{array}{l}0.432 \\
\mathbf{0 . 0 2}\end{array}$ & & $\begin{array}{l}-0.403 \\
\mathbf{0 . 0 3}\end{array}$ & $\begin{array}{l}-0.391 \\
\mathbf{0 . 0 0 3}\end{array}$ & - & - & - & - & - \\
\hline & Th & - & $\begin{array}{l}0.394 \\
\mathbf{0 . 0 3}\end{array}$ & - & - & - & - & - & - & - & - & - \\
\hline & $\mathrm{U}$ & $\begin{array}{l}-0.497 \\
\mathbf{0 . 0 0 6}\end{array}$ & - & $\begin{array}{l}0.444 \\
\mathbf{0 . 0 1}\end{array}$ & - & - & - & - & - & - & - & - \\
\hline & V & - & $\begin{array}{l}0.544 \\
\mathbf{0 . 0 0 2}\end{array}$ & - & $\begin{array}{l}-0.407 \\
\mathbf{0 . 0 2}\end{array}$ & - & - & - & - & - & - & - \\
\hline \multirow[t]{7}{*}{ Monsoon } & As & - & - & - & - & - & - & - & - & $\begin{array}{l}0.402 \\
\mathbf{0 . 0 2}\end{array}$ & & \\
\hline & $\mathrm{Ba}$ & - & - & - & - & $\begin{array}{l}0.426 \\
\mathbf{0 . 0 2}\end{array}$ & $\begin{array}{l}0.421 \\
\mathbf{0 . 0 1}\end{array}$ & - & - & - & - & - \\
\hline & $\mathrm{Cr}$ & - & - & - & - & - & - & $\begin{array}{l}0.437 \\
\mathbf{0 . 0 1}\end{array}$ & - & - & - & - \\
\hline & $\mathrm{Cu}$ & - & - & - & - & $\begin{array}{l}0.362 \\
\mathbf{0 . 0 4}\end{array}$ & $\begin{array}{l}0.384 \\
\mathbf{0 . 0 3}\end{array}$ & & - & - & - & - \\
\hline & $\mathrm{Fe}$ & - & - & $\begin{array}{l}0.386 \\
\mathbf{0 . 0 3}\end{array}$ & - & - & - & - & - & - & - & - \\
\hline & Mo & - & - & - & - & - & - & - & - & $\begin{array}{l}0.408 \\
\mathbf{0 . 0 0 2}\end{array}$ & - & - \\
\hline & Th & - & $\begin{array}{l}0.459 \\
\mathbf{0 . 0 1}\end{array}$ & - & - & - & - & - & - & - & - & - \\
\hline
\end{tabular}




\begin{tabular}{|c|c|c|c|c|c|c|c|c|c|c|c|c|}
\hline & $\mathrm{Tl}$ & - & - & - & $\begin{array}{l}0.426 \\
\mathbf{0 . 0 1}\end{array}$ & - & - & - & - & - & $\begin{array}{l}0.396 \\
\mathbf{0 . 0 3}\end{array}$ & - \\
\hline & $\mathrm{U}$ & $\begin{array}{l}0.496 \\
\mathbf{0 . 0 0 5}\end{array}$ & $\begin{array}{l}0.461 \\
\mathbf{0 . 0 0 1}\end{array}$ & $\begin{array}{l}0.714 \\
\mathbf{0 . 0 0 0 9}\end{array}$ & - & $\begin{array}{l}0.551 \\
\mathbf{0 . 0 0 1}\end{array}$ & $\begin{array}{l}0.534 \\
\mathbf{0 . 0 0 2}\end{array}$ & - & $\begin{array}{l}0.404 \\
\mathbf{0 . 0 2}\end{array}$ & $\begin{array}{l}0.681 \\
\mathbf{0 . 0 0 5}\end{array}$ & $\begin{array}{l}-0.407 \\
\mathbf{0 . 0 2}\end{array}$ & - \\
\hline & $\mathrm{V}$ & - & - & - & - & - & $\begin{array}{l}0.414 \\
\mathbf{0 . 0 2}\end{array}$ & - & $\begin{array}{l}0.521 \\
\mathbf{0 . 0 2}\end{array}$ & - & - & - \\
\hline \multirow[t]{12}{*}{ Post-Monsoon } & $\mathrm{Al}$ & - & - & - & - & - & - & - & - & - & - & $\begin{array}{l}0.457 \\
\mathbf{0 . 0 1}\end{array}$ \\
\hline & As & - & - & $\begin{array}{l}0.412 \\
\mathbf{0 . 0 2}\end{array}$ & - & - & - & - & - & - & - & - \\
\hline & $\mathrm{Ba}$ & $\begin{array}{l}0.451 \\
\mathbf{0 . 0 1}\end{array}$ & $\begin{array}{l}0.532 \\
\text { 0.002 }\end{array}$ & $\begin{array}{l}0.604 \\
\mathbf{0 . 0 0 5}\end{array}$ & $\begin{array}{l}-0.495 \\
\mathbf{0 . 0 0 6}\end{array}$ & $\begin{array}{l}0.669 \\
\mathbf{0 . 0 0 7}\end{array}$ & $\begin{array}{l}0.624 \\
\mathbf{0 . 0 0 3}\end{array}$ & $\begin{array}{l}0.571 \\
\mathbf{0 . 0 0 1}\end{array}$ & $\begin{array}{l}0.794 \\
\mathbf{0 . 0 0 2}\end{array}$ & $\begin{array}{l}0.798 \\
\mathbf{0 . 0 0 2}\end{array}$ & $\begin{array}{l}-0.618 \\
\mathbf{0 . 0 0 3}\end{array}$ & - \\
\hline & $\mathrm{Cr}$ & - & - & $\begin{array}{l}-0.577 \\
\mathbf{0 . 0 0 1}\end{array}$ & - & $\begin{array}{l}-0.480 \\
\mathbf{0 . 0 0 8}\end{array}$ & $\begin{array}{l}-0.503 \\
\mathbf{0 . 0 0 5}\end{array}$ & $\begin{array}{l}-0.697 \\
\mathbf{0 . 0 0 2}\end{array}$ & $\begin{array}{l}-0.730 \\
\mathbf{0 . 0 0 6}\end{array}$ & $\begin{array}{l}-0.769 \\
\mathbf{0 . 0 0 1}\end{array}$ & $\begin{array}{l}0.630 \\
\mathbf{0 . 0 0 2}\end{array}$ & - \\
\hline & $\mathrm{Cu}$ & - & - & - & - & - & - & $\begin{array}{l}0.508 \\
\mathbf{0 . 0 0 4}\end{array}$ & - & - & - & - \\
\hline & $\mathrm{Fe}$ & - & - & - & - & - & - & $\begin{array}{l}0.555 \\
\mathbf{0 . 0 0 1}\end{array}$ & $\begin{array}{l}0.663 \\
\mathbf{0 . 0 0 9}\end{array}$ & $\begin{array}{l}0.800 \\
\text { 0.001 }\end{array}$ & $\begin{array}{l}-0.726 \\
\mathbf{0 . 0 0 8}\end{array}$ & - \\
\hline & $\mathrm{Mn}$ & - & - & - & - & - & - & $\begin{array}{l}-0.638 \\
\mathbf{0 . 0 0 1}\end{array}$ & $\begin{array}{l}-0.657 \\
\mathbf{0 . 0 0 1}\end{array}$ & $\begin{array}{l}-0.651, \\
\mathbf{0 . 0 0 1}\end{array}$ & $\begin{array}{l}0.525 \\
\mathbf{0 . 0 0 3}\end{array}$ & - \\
\hline & Mo & & $\begin{array}{l}0.595 \\
\text { 0.006 }\end{array}$ & $\begin{array}{l}0.744 \\
\mathbf{0 . 0 0 3}\end{array}$ & & $\begin{array}{l}0.736 \\
0.007\end{array}$ & $\begin{array}{l}0.732 \\
0.006\end{array}$ & - & - & $\begin{array}{l}0.402, \\
\mathbf{0 . 0 2}\end{array}$ & - & - \\
\hline & $\mathrm{Th}$ & - & - & - & - & - & - & $\begin{array}{l}-0.525 \\
\mathbf{0 . 0 0 3}\end{array}$ & $\begin{array}{l}-0.594 \\
\mathbf{0 . 0 0 6}\end{array}$ & $\begin{array}{l}-0.616 \\
\mathbf{0 . 0 0 3}\end{array}$ & $\begin{array}{l}0.511, \\
\text { 0.004 }\end{array}$ & - \\
\hline & $\mathrm{Tl}$ & - & - & - & - & - & - & - & $\begin{array}{l}-0.491 \\
\mathbf{0 . 0 0 6}\end{array}$ & $\begin{array}{l}-0.381, \\
\mathbf{0 . 0 4}\end{array}$ & $\begin{array}{l}0.489 \\
0.006\end{array}$ & - \\
\hline & $\mathrm{U}$ & $\begin{array}{l}0.507 \\
\mathbf{0 . 0 0 5}\end{array}$ & $\begin{array}{l}0.645 \\
\mathbf{0 . 0 0 1}\end{array}$ & $\begin{array}{l}0.825 \\
\mathbf{0 . 0 0 3}\end{array}$ & $\begin{array}{l}-0.533 \\
\mathbf{0 . 0 0 1}\end{array}$ & $\begin{array}{l}0.811 \\
\mathbf{0 . 0 0 9}\end{array}$ & $\begin{array}{l}0.828 \\
\mathbf{0 . 0 0 2}\end{array}$ & $\begin{array}{l}-0.458 \\
\mathbf{0 . 0 1}\end{array}$ & $\begin{array}{l}-0.398 \\
\mathbf{0 . 0 3}\end{array}$ & $\begin{array}{l}-0.433, \\
\mathbf{0 . 0 1}\end{array}$ & - & - \\
\hline & $\mathrm{V}$ & & & $\begin{array}{l}0.512 \\
0.02\end{array}$ & & & $\begin{array}{l}0.375 \\
0.04\end{array}$ & $\begin{array}{l}0.522 \\
\mathbf{0 . 0 0 3}\end{array}$ & & $\begin{array}{l}0.434 \\
\text { 0.01 }\end{array}$ & $\begin{array}{l}-0.555 \\
\mathbf{0 . 0 0 1}\end{array}$ & \\
\hline
\end{tabular}


Most of the metals of post-COVID-19 were correlated with physical parameters in the postmonsoon season (Table 5). However, an increased number of correlations between metals and physical parameters were observed in post-COVID-19 than in the pre-COVID-19 scenarios. The metals like $\mathrm{Ba}$ and $\mathrm{U}$ were positively correlated with physical parameters except DO in the pre-COVID-19 scenario. Consequently, Ba was positively correlated with $\mathrm{pH}, \mathrm{A}_{\mathrm{T}}$, salinity and negatively correlated with TDS. Whereas $U$ was negatively correlated with $\mathrm{pH}, \mathrm{A}_{\mathrm{T}}$ and salinity in post-COVID-19. Similarly, Mn was negatively correlated with $\mathrm{pH}, \mathrm{A}_{\mathrm{T}}$ and salinity and positively correlated with TDS. On the other hand, Fe was positively correlated with $\mathrm{pH}$, $\mathrm{A}_{\mathrm{T}}$ and salinity and negatively correlated with TDS in the post-COVID-19 scenarios (Table 5)

\section{DISCUSSION}

Coastal ecosystems receive a large influx of anthropogenic contaminants through riverine input and these contaminants are reflected in the water, sediment, and associated biodiversity of these ecosystems (Nazneen et al., 2019; Vijay Prakash et al., 2021; Lotliker et al., 2021). Our results suggest a similar phenomenon, where the COVID-19 induced lockdown has halted various industries and human activities and resulted in the reduction of various metals in the water samples of the Chilika lagoon. The Chilika lagoon has a high influence of the seasonal influx of freshwater during the monsoon season, which also brings a large quantity of dissolved organic materials, which can also influence the metal content in the water column (Panda et al., 2010; Sahu et al., 2014; Barik et al., 2018). This seasonal influx of materials and mixing with saline water also influences the physical parameters of the lagoon between the three sectors, which are evident in the results irrespective of the COVID-19 scenarios.

The lockdown induced due to COVID-19 was a blessing in disguise, where humanderived impacts were reduced through the shutdown of industrial activities (Muhammad et al., 2020). One of the major rivers that supply water to the Chilika lagoon is the river Mahanadi (61\% inflow), which passes through Indian states of Chhattisgarh and Odisha (Mishra and Dwibedy, 2015; Hussain et al., 2020). In general, this river along with 53 more small river tributaries brings the majority of the influx of various contaminants from the small scales industries, agricultural and mining fields into the Chilika lagoon ecosystem (Sundaray et al., 2012; Mohanty and Samanta, 2016; Hussain et al., 2020). As a result, most of the metals like $\mathrm{Al}, \mathrm{As}, \mathrm{Fe}, \mathrm{Th}, \mathrm{U}$, and V were higher in the pre-COVID-19 scenarios (Fig.4). Even though the metals like $\mathrm{Ba}, \mathrm{Mo}, \mathrm{Sr}$, and $\mathrm{Tl}$ that were not statistically significant were also higher in preCOVID-19 scenarios along with metals $\mathrm{Be}, \mathrm{Cd}$, and Ni which were observed in below detection limit in more than one sector (See Supplementary Table 1 and Fig.1). However, certain metals like $\mathrm{Cr}, \mathrm{Cu}, \mathrm{Mn}$, and $\mathrm{Pb}$ were only 1-fold higher in the post-COVID-19 scenario than the preCOVID-19, which suggests that these metals were incorporated into the water column through the natural, seasonal and biogeochemical processes of the system which remained the same, even during shutdown of industrial inputs (Barik et al., 2018; Nazneen et al., 2019).

Seasonal and sectoral influence is predominant in this lagoon ecosystem, where the northern sectors receive the highest influx of freshwater and the southern sector the lowest, whereas the central sector of the lagoon acts as a permeable sector between fresh and saline water (Panigrahi et al., 2007; Rajawat et al., 2007; Sahu et al., 2014; Barik et al., 2018). The Indian monsoon arrived in the state of Odisha on June 11 and 12 for the years 2019 and 2020 respectively (IMD, 2019, 2020) suggesting that the influence of the onset of monsoon season on the variation of metal content was minimum. Further, the water influx during both monsoon periods was not different and had very low variability between both years (IMD, 2020), probably diminishing the effect of monsoon on metal concentration. However, it has been 
observed that most of the metal concentrations remains higher either in pre-monsoon or postmonsoon seasons, except for few metals like Mn and U in pre-COVID-19 scenarios and Cr, Fe, and $\mathrm{U}$ in post-COVID-19 scenarios (Fig.4). Mostly in the monsoon season, the standard deviation of metals concentration was significantly higher compared to the pre-monsoon and post-monsoon seasons. This was particularly due to the dilution effect as the freshwater in high quantities enters into the lagoon during the monsoon period. Secondly, higher standard deviation between the sampling stations of individual sector reflects the internal dynamics of the lagoon, i.e., distance from the landward or seaward influence, local macrophytes, and fishing activities (Amir et al., 2019; Nazneen et al., 2019a).

Consequently, there is a significant variation in salinity, $\mathrm{A}_{\mathrm{T}}$, TDS, and $\mathrm{EC}$ along with the three sectors of the lagoon, which was also evident in our results (Table 1 and 2). Even though the variation in $\mathrm{pH}$ and $\mathrm{DO}$ were not statistically different between COVID-19 scenarios, there were significant variations between seasons and sectors. The positive correlation between these physical parameters and metals indicates the effect of change in physical parameters in controlling the metal concentration (Nazneen et al., 2019). These results also indicates that, the seasonal influence was more relevant in the post-monsoon seasons in both COVID-19 scenarios, with an increasingly higher number of correlations of physical parameters with metal concentrations (Table 5). The high values of TDS in the water samples of the lagoon in the post-COVID-19 scenario could be the reason for the high concentration of $\mathrm{Cr}$ and $\mathrm{Mn}$. Consequently, these two metals also had a positive correlation with TDS in the post-COVID-19 scenarios (Table 5).

Other than the seasons and sectoral differences during COVID-19 scenarios, the three sectors of the lagoon were dominant by different macrophytes and macroalgae, such as seagrass are dominant in the southern sector, the central sector is dominant by macroalgae, and the northern sector by freshwater macroalgae and saltmarsh plants, which also play an important role in bioaccumulation of these metals and metal cycling (Sanz-Lázaro et al., 2012; Bonanno et al., 2017). The role of these macrophytes in sector-wise productivity that leads to variation in metal accumulation, cycling, and release of sediment-bound metals has also been observed in the Chilika lagoon (Amir et al., 2019).

\section{Conclusion}

COVID-19 is declared as a pandemic across the globe during which most of the industrial and human-derived activities were restricted under the lockdown period. This provided an opportunity to assess the effects of this lockdown on various natural ecosystems, which otherwise would have been impossible to replicate. In the present study, the metal concentration in the water column of the Chilika lagoon in pre-and post-COVID-19 scenarios were compared. Lower concentrations of various metals have been observed in the postCOVID-19 scenarios than in pre-COVID-19 conditions. This led to conclude that halt of industrial and mining activities in the catchment area has resulted in lowering the concentration of these metals in the lagoon ecosystem. Consequently, certain metals like $\mathrm{Cr}$ and $\mathrm{Mn}$ concentration have shown 1-fold higher concentrations in the post-COVID-19 scenario, suggesting the complex internal dynamics of the lagoon, which is mainly driven by salinity and macrophytes. The results of this study can be used as a baseline for metal concentrations in the surface water of this lagoon system. This study also suggests that, the lockdown induced due to COVID-19 reduced the metal concentrations to some extent, but the natural biogeochemical process and seasonal influence of monsoon on the lagoon are more evident in the variation of metals in the three sectors than COVID-19 scenarios. 


\section{Acknowledgments}

We are thankful to World Bank for their help in establishing laboratory facilities used for analysis of the water samples of this project through their grant no. (Credit No. 4765-IN) given to CDA under the Integrated Coastal Zone Management Project (ICZMP) of Odisha. We are also thankful to the research staffs of CDA for their generous help during field and laboratory analysis.

\section{References}

Amir, M., Paul, D., Samal, R.N., 2019. Sources of organic matter in Chilika lagoon, India inferred from stable $\mathrm{C}$ and $\mathrm{N}$ isotopic compositions of particulates and sediments. Journal of Marine Systems 194, 81-90. https://doi.org/10.1016/j.jmarsys.2019.03.001

Avelar, M., Bonilla-Heredia, B., Merino-Ibarra, M., Herrera-Silveira, J.A., Ramirez, J., Rosas, H., Valdespino, J., Carricart-Ganivet, J.P., Martínez, A., 2013. Iron, cadmium, and chromium in seagrass (Thalassia testudinum) from a coastal nature reserve in karstic Yucatán. Environmental Monitoring and Assessment 185, 7591-7603. https://doi.org/10.1007/s10661-013-3121-7

Banerjee, S., Pramanik, A., Sengupta, S., Chattopadhyay, D., Bhattacharyya, M., 2017. Distribution and source identification of heavy metal concentration in Chilika Lake, Odisha India: An assessment over salinity gradient. Current Science 112, 87-94. https://doi.org/10.18520/cs/v112/i01/87-94

Barik, S.K., Bramha, S., Bastia, T.K., Behera, D., Mohanty, P.K., Rath, P., 2019. Distribution of geochemical fractions of phosphorus and its ecological risk in sediment cores of a largest brackish water lake, South Asia. International Journal of Sediment Research 34, 251-261. https://doi.org/10.1016/j.ijsrc.2018.11.004

Barik, S.K., Muduli, P.R., Mohanty, B., Rath, P., Samanta, S., 2018. Spatial distribution and potential biological risk of some metals in relation to granulometric content in core sediments from Chilika Lake, India. Environmental Science and Pollution Research 25, 572-587. https://doi.org/10.1007/s11356-017-0421-4

Barik, S.S., Prusty, P., Singh, R.K., Tripathy, S., Farooq, S.H., Sharma, K., 2020. Seasonal and spatial variations in elemental distributions in surface sediments of Chilika Lake in response to change in salinity and grain size distribution. Environmental Earth Sciences 79, 1-18. https://doi.org/10.1007/s12665-020-09009-z

Bonanno, G., Borg, J.A., di Martino, V., 2017. Levels of heavy metals in wetland and marine vascular plants and their biomonitoring potential: A comparative assessment. Science of the Total Environment 576, 796-806. https://doi.org/10.1016/j.scitotenv.2016.10.171

Cascella, M., Rajnik, M., Cuomo, A., Dulebohn, S. C., Di Napoli, R., 2020. Features, Evaluation and Treatment Coronavirus (COVID-19). In Stat Pearls [internet]. Treasure Island, FL: Stat Pearls Publishing.

CDA (Chilika Development Authority), 2021. Press release on monitoring of Chilika lake on $15^{\text {th }}$ January, 2021. https://www.chilika.com/documents/newsevents_1610975333.pdf

Ganguly, D., Patra, S., Muduli, P.R., Vishnu Vardhan, K., R, A.K., Robin, R.S., Subramanian, B.R., n.d. Influence of nutrient input on the trophic state of a tropical brackish water lagoon. 
Garg, V., Aggarwal, S.P., Chauhan, P., 2020. Changes in turbidity along Ganga River using Sentinel-2 satellite data during lockdown associated with COVID-19. Geomatics, Natural Hazards and Risk 11, 1175-1195. https://doi.org/10.1080/19475705.2020.1782482

Gopal, V., Shanmugasundaram, A., Nithya, B., Magesh, N.S., Jayaprakash, M., 2018. Water quality of the Uppanar estuary, Southern India: Implications on the level of dissolved nutrients and trace elements. Marine Pollution Bulletin 130, 279-286. https://doi.org/10.1016/j.marpolbul.2018.03.046

Häder, D.P., Banaszak, A.T., Villafañe, V.E., Narvarte, M.A., González, R.A., Helbling, E.W., 2020. Anthropogenic pollution of aquatic ecosystems: Emerging problems with global implications. Science of the Total Environment. https://doi.org/10.1016/j.scitotenv.2020.136586

Hussain, J., Dubey, A., Hussain, I., Arif, Mohd., Shankar, A., 2020. Surface water quality assessment with reference to trace metals in River Mahanadi and its tributaries, India. Applied Water Science 10, 1-12. https://doi.org/10.1007/s13201-020-01277-1

Lakshman, N., Priyadarsini, P.M., Das, S.S., 2015. Bioaccumulation of Trace Metals in Two Species of Crabs from Chilika Lagoon, East Coast of India. Journal of Atmosphere 1, 17. https://doi.org/10.18488/journal.94/2015.1.1/94.1.1.7

Lewis, M.A., Richard, D., 2009. Non-nutrient anthropogenic chemicals in seagrass ecosystems: Fate and effects. Environmental Toxicology and Chemistry 28, 644-661. https://doi.org/10.1897/08-201.1

Lokhandwala, S., Gautam, P., 2020. Indirect impact of COVID-19 on environment: A brief study in Indian context. Environmental Research 188. https://doi.org/10.1016/j.envres.2020.109807

Lotliker, A.A., Baliarsingh, S.K., Shesu, R.V., Samanta, A., Naik, R.C., Balakrishnan Nair, T.M., 2021. Did the Coronavirus Disease 2019 Lockdown Phase Influence Coastal Water Quality Parameters off Major Indian Cities and River Basins? Frontiers in Marine Science 8, 1-11. https://doi.org/10.3389/fmars.2021.648166

Madhusmita, T., 2012. Biodiversity of Chilika and Its Conservation, Odisha, India. Int. Res. J. Environment Sci. International Science Congress Association 1, 54-57.

Millero, F., Woosley, R., DiTrolio, B., Waters, J., 2009. Effect of Ocean Acidification on the Speciation of Metals in Seawater. Oceanography. https://doi.org/10.5670/oceanog.2009.98

Mishra, A.K., Santos, R., Hall -Spencer, J.M., 2019. Elevated trace elements in sediments and seagrasses at CO2 seeps. Marine Environmental Research 104810. https://doi.org/10.1016/j.marenvres.2019.104810

Mishra, D.R., Kumar, A., Muduli, P.R., Equeenuddin, S.M., Rastogi, G., Acharyya, T., Swain, D., 2020. Decline in phytoplankton biomass along Indian coastalwaters due to COVID-19 lockdown. Remote Sensing 12. https://doi.org/10.3390/RS12162584

Mishra, P., Panda, U.S., Pradhan, U., Kumar, C.S., Naik, S., Begum, M., Ishwarya, J., 2015. Coastal water quality monitoring and modelling off Chennai city, in: Procedia Engineering. Elsevier Ltd, pp. 955-962. https://doi.org/10.1016/j.proeng.2015.08.386 
Mishra, S.P., Dwibedy, S., 2015. Geohydrology of South Mahanadi Delta and Chilika Lake, Odisha. International Journal of Advanced Research 3, 430-444.

Mohanty, B., Muduli, P.R., Behera, A.T., Mahapatro, D., Barik, S.K., Nag, S.K., Samal, R.N., Pattnaik, A.K., 2016. Assessment of petroleum hydrocarbon in a tropical brackish water lagoon: Chilika, India. Chemistry and Ecology 32, 653-668. https://doi.org/10.1080/02757540.2016.1177521

Mohanty, D., Samanta, L., 2016. Multivariate analysis of potential biomarkers of oxidative stress in Notopterus notopterus tissues from Mahanadi River as a function of concentration of heavy metals. Chemosphere 155, 28-38. https://doi.org/10.1016/j.chemosphere.2016.04.035

Morsy, K.M., Mishra, A.K., 2020. Water Quality Assessment of the Nile Delta Lagoons. https://doi.org/10.1177/1178622120963072

Muhammad, S., Long, X., Salman, M., 2020. COVID-19 pandemic and environmental pollution: A blessing in disguise? Science of the Total Environment 728, 138820. https://doi.org/10.1016/j.scitotenv.2020.138820

Nayak, B.K., Acharya, B.C., Panda, U.C., Nayak, B.B., Acharya, S.K., 2004. Variation of water quality in Chilika lake, Orissa. Indian Journal of Marine Sciences 33, 164-169.

Nazneen, S., Raju, N.J., Madhav, S., Ahamad, A., 2019a. Spatial and temporal dynamics of dissolved nutrients and factors affecting water quality of Chilika lagoon. Arabian Journal of Geosciences 12. https://doi.org/10.1007/s12517-019-4417-x

Nazneen, S., Singh, S., Raju, N.J., 2019b. Heavy metal fractionation in core sediments and potential biological risk assessment from Chilika lagoon, Odisha state, India. Quaternary International 507, 370-388. https://doi.org/10.1016/j.quaint.2018.05.011

Panda, B.P., Panda, B., Parida, S.P., Mahapatra, B., Dash, A.K., Pradhan, A., 2019. Heavy metal accumulation in some fishes preferred for consumption by egrets in Odisha, India. Nature Environment and Pollution Technology 18, 975-979.

Panda, U.C., Rath, P., Bramha, S., Sahu, K.C., 2010. Application of Factor Analysis in Geochemical Speciation of Heavy Metals in the Sediments of a Lake System-Chilika (India): A Case Study. Journal of Coastal Research 265, 860-868. https://doi.org/10.2112/08-1077.1

Panda, U.S., Mahanty, M.M., Ranga Rao, V., Patra, S., Mishra, P., 2015. Hydrodynamics and water quality in Chilika Lagoon-A modelling approach, in: Procedia Engineering. Elsevier Ltd, pp. 639-646. https://doi.org/10.1016/j.proeng.2015.08.337

Parida, S., Barik, S.K., Mohanty, B., Muduli, P.R., Mohanty, S.K., Samanta, S., Pattanaik, A.K., 2017. Trace metal concentrations in euryhaline fish species from Chilika lagoon: human health risk assessment. International Journal of Environmental Science and Technology 14, 2649-2660. https://doi.org/10.1007/s13762-017-1334-y

Patel, P.P., Mondal, S., Ghosh, K.G., 2020. Some respite for India's dirtiest river? Examining the Yamuna's water quality at Delhi during the COVID-19 lockdown period. Science of the Total Environment 744, 140851. https://doi.org/10.1016/j.scitotenv.2020.140851

Richir, J., Gobert, S., 2014. A reassessment of the use of Posidonia oceanica and Mytilus galloprovincialis to biomonitor the coastal pollution of trace elements: New tools and 
tips. Marine Pollution Bulletin 89, 390-406.

https://doi.org/10.1016/j.marpolbul.2014.08.030

Sahoo, R.K., Mohanty, P.K., Pradhan, S., Pradhan, U.K., Samal, R.N., 2018. Bed sediment characteristics and transport processes along the inlet channel of Chilika Lagoon (India). Indian Journal of Geo-Marine Sciences 47, 301-307.

Sahu, B.K., Pati, P., Panigrahy, R.C., 2014. Environmental conditions of Chilika Lake during pre and post hydrological intervention: An overview. Journal of Coastal Conservation 18, 285-297. https://doi.org/10.1007/s11852-014-0318-z

Sanz-Lázaro, C., Malea, P., Apostolaki, E.T., Kalantzi, I., Marín, a., Karakassis, I., 2012. The role of the seagrass Posidonia oceanica in the cycling of trace elements. Biogeosciences 9, 2497-2507. https://doi.org/10.5194/bg-9-2497-2012

Shukla, T., Sen, I.S., Boral, S., Sharma, S., 2021. A time-series record during COVID-19 lockdown shows the high resilience of dissolved heavy metals in the Ganga river. Environmental Science and Technology Letters. https://doi.org/10.1021/acs.estlett.0c00982

Stockdale, A., Tipping, E., Lofts, S., Mortimer, R.J.G., 2016. Effect of Ocean Acidification on Organic and Inorganic Speciation of Trace Metals. Environmental Science and Technology 50, 1906-1913. https://doi.org/10.1021/acs.est.5b05624

Sundaray, S.K., Nayak, B.B., Kanungo, T.K., Bhatta, D., 2012. Dynamics and quantification of dissolved heavy metals in the Mahanadi River estuarine system, India. Environmental Monitoring and Assessment 184, 1157-1179. https://doi.org/10.1007/s10661-011-2030$\mathrm{x}$

Tripathy, G.R., Singh, S.K., Ramaswamy, V., 2014. Major and trace element geochemistry of Bay of Bengal sediments: Implications to provenances and their controlling factors. Palaeogeography, Palaeoclimatology, Palaeoecology 397, 20-30. https://doi.org/10.1016/j.palaeo.2013.04.012

Vijay Prakash, K., Geetha Vimala, Ch.S., Preethi Latha, T., Jayaram, C., Nagamani, P. v., Laxmi, Ch.N. v., 2021. Assessment of Water Quality Along the Southeast Coast of India During COVID-19 Lockdown. Frontiers in Marine Science 8, 1-13. https://doi.org/10.3389/fmars.2021.659686

WHO, 2021. World Health Organization, Weekly Update on COVID-19. https://www.who.int/publications/m/item/weekly-epidemiological-update-on-covid-19--11-may-2021 